Received:

$11-\mathrm{XI}-2020$

Accepted:

2-II-2021

Published Online: 15-III-2021

\section{Clinical Management of Endo-Perio Lesion Through Guided Tissue Regeneration: a 5 Year Follow-Up}

\section{Manejo clínico de una lesión endo-perio a través de la regeneración tisular guiada: control post-operatorio de 5 años}

Munis Mukhtar BDS, MSc, FICOI, DICOI'; Maaz Asad BDS, MDSc²; Asaad Javaid Mirza BDS, MCPS, MDS ${ }^{3}$

1. Oral Implantologist, Karachi, Pakistan. https://orcid.org/0000-0001-6001-4015

2. Periodontist, Baqai Dental college, Karachi, Pakistan. https://orcid.org/0000-0002-8755-8159

3. Endodontist, Baqai Dental College, Karachi, Pakistan. https://orcid.org/0000-0002-6735-0393

Correspondence to: Dr. Munis Mukhtar - drmunis78@hotmail.com

ABSTRACT: Progressive periodontal disease causes loss of supporting structures of teeth resulting in deep bony defects. In this case a report of 22-year old female patient is being presented with clinical findings of vertical bone loss in two adjacent teeth, on distal surface of 2nd upper right premolar and mesial surface of upper right 1st molar. Root canal treatment, non-surgical periodontal therapy followed by guided tissue regeneration was carried out using decalcified freeze-dried bone allograft (DFDBA) and collagen membrane. Analysis of clinical and radiographic findings showed marked reduction in pocket depth up to $12 \mathrm{~mm}$ with hard tissue repair on 3-month, 2-year and 5- year follow ups.

KEYWORDS: Endo perio lesion; GTR; Root planning; Hard tissue repair; RCT; Periodontal disease.

RESUMEN: La enfermedad periodontal progresiva provoca la pérdida de las estructuras de soporte de los dientes, lo que resulta en defectos óseos profundos. En este caso clínico se presenta un informe de una paciente de 22 años con pérdida ósea vertical en la superficie distal del segundo premolar superior derecho y en la superficie mesial del primer molar superior derecho. El tratamiento del conducto radicular, la terapia periodontal no quirúrgica seguida de la regeneración tisular guiada se llevó a cabo utilizando aloinjerto óseo liofilizado descalcificado (DFDBA) y membrana de colágeno. 
El análisis de los hallazgos clínicos y radiográficos mostró una marcada reducción en la profundidad de la bolsa de hasta $12 \mathrm{~mm}$ con reparación de tejido duro en seguimientos de 3 meses, 2 años y 5 años.

PALABRAS CLAVE: Lesión endo perio, alisado radicular, Enfermedad periodontal.

\section{INTRODUCTION}

With the recent advancements in dental sciences, clinicians are more interested in saving the periodontal structures to give longevity to the dentition by providing optimum level of health. Periodontics not only aims to prevent the disease but also aims to do corrective or constructive procedures caused by the spread of those diseases.

Periodontal diseases lead to alveolar bone defect resulting in loss of bone and other components of periodontal apparatus (1) which if remained untreated, consequently leads to loss of a natural tooth. Bone loss may be vertical, horizontal or at times both. Earlier it was believed that subjects with advanced periodontitis having uncertain prognosis of the teeth which has however been proved otherwise through Guided tissue regeneration (GTR). It is an established clinical method for bone repair and regeneration in cases which appear questionable in prognosis to the attending dental practitioner. GTR can be accomplished with or without bone grafting. The bone grafts used in this connection include autograft, xenograft, alloplast and allograft. Among the available grafts, autograft and decalcified freeze-dried bone allograft (DFDBA) have shown potential in periodontal regeneration (2). DFDBA has osteoconductive activity as it contains bone morphogenic proteins. Decalcification of graft activates bone inductive proteins which lead to formation of new attachments.

This case report aims to show a successfully managed clinical case having endo-perio lesion and modus operandi for its evidence-based treatment which allows for maintaining teeth that may be judged as questionable in prognosis. It not only saved the tooth and increased longevity of its life but also saved the patient from undergoing agony of losing one of her load bearing teeth.

\section{CASE REPORT}

A 22-year old female patient presented in our private dental practice set up with complaint of pain, food stagnation, foul smell and loosening of couple of teeth in upper jaw. Intraoral examination revealed vertical bone loss around distal surface of upper right second premolar and mesial surface of first molar (Figure 1). The pocket depth was measured to be more than $15 \mathrm{~mm}$ (Figure 2). The severely affected premolar and molar, on pulp testing showed pulpal involvement leading to diagnosis of endo-periodontal lesion.

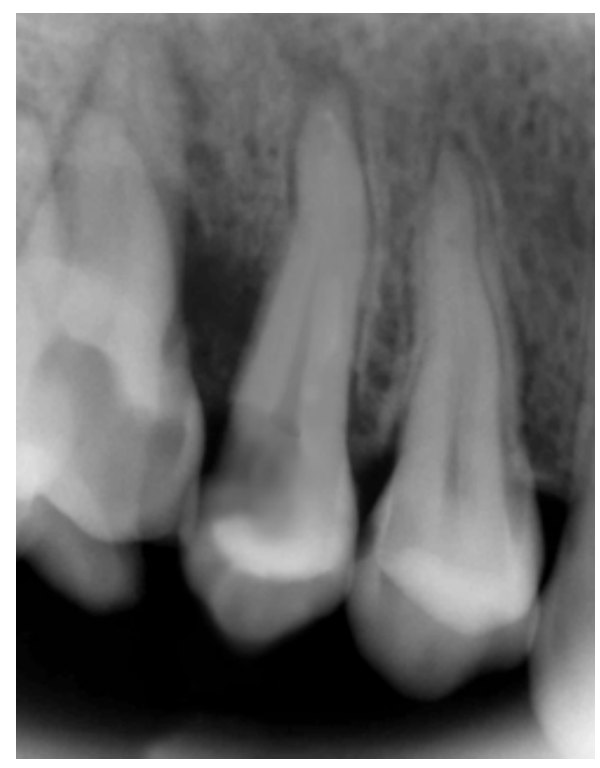

Figure 1. Hard tissue defect at $15 \& 16$. 


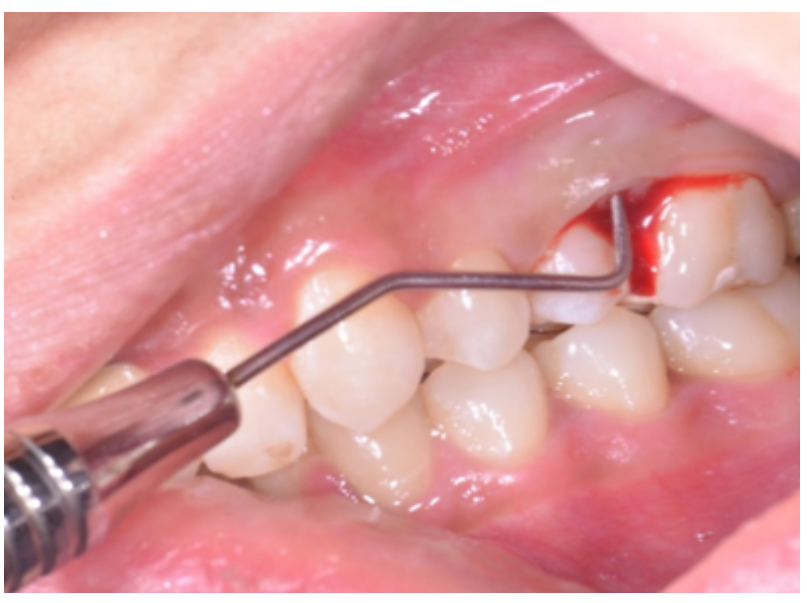

Figure 2. Pocket depth of more than $15 \mathrm{~mm}$.

The patient was detailed about the four likely solutions to her problem:

- Extraction of 2nd premolar and molar followed by removable partial denture.

- Extraction of the teeth and fixed partial denture.

- Extraction of the teeth followed by implant placement.

- Root canal therapy (RCT) and Regenerative periodontal treatment.

She readily opted for fourth option and preferred to undergo RCT and regenerative periodontal treatment to get her affected teeth saved. First molar and 2nd premolar, therefore, were first treated endodontically to eliminate the source of infection from the defective site. The root canal procedure was completed in single visit followed by thorough scaling and root planing with $\mathrm{OHI}$ instructions.

After 4 weeks, surgical intervention was carried out. Under local anesthesia a full thickness mucoperiosteal flap was reflected to entirely expose the underlying bony defect (Figure 3). Scaling and root planing was again carried out with osteoplasty to make sure the site becomes clean and non-infected. Freeze-dried bone allograft (surreoss) 0.5cc powder was condensed into the bone defect (Figure 4) and 1x2cm Acellular Dermal
Matrix Membrane (Surederm) was placed over the graft area to prevent the epithelial cell migration (Figure 5). Finally, interrupted silk (4/0) suture were placed to approximate the soft tissue (Figure 6). Post-operative instructions were given and patient was directed to use chlorhexidine gel and rinse three times for a period of 15 days and suitable antibiotics were prescribed for five days. As the prognosis of tooth was highly questionable patient was recalled on follow up after 1 week, 2 weeks and 4 weeks. After 3-months' patient's intraoral radiograph showed remarkable improvement in regard to bone repair and patient's satisfaction (Figure 7). Clinical evaluation on 3-month, 2-year and 5-year recall exhibited marked reduction in pocket depth up to $12 \mathrm{~mm}$ with radiographic evidence of further hard tissue repair (Figure 8). A 5-year recall showed a stable probing depth of $3 \mathrm{~mm}$ with functionally standing in her oral cavity despite the fact that she refused to have a crown on the treated tooth (Figure 9).

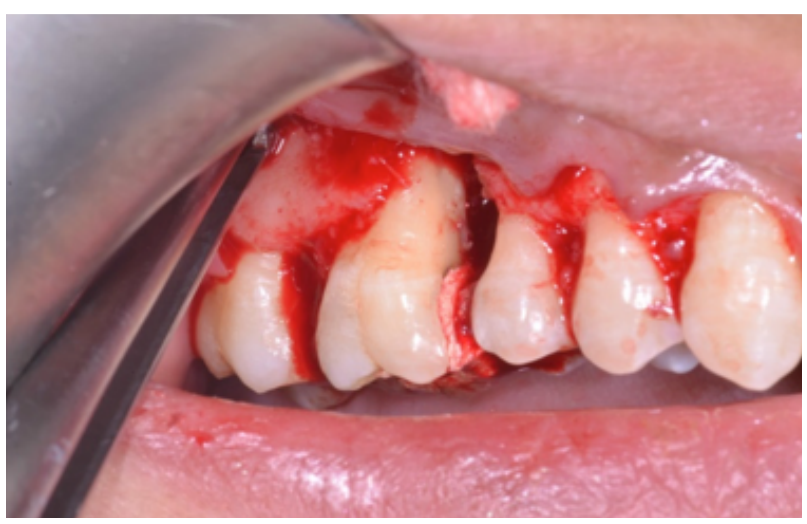

Figure 3. Bony defect exposed.

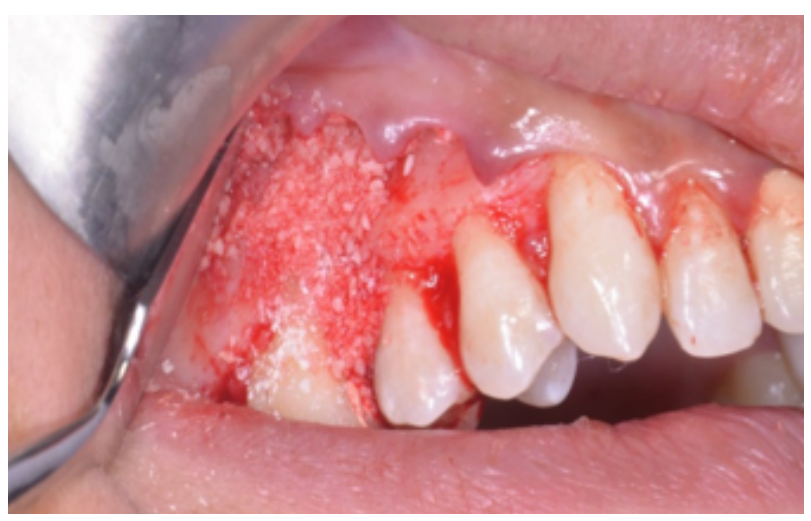

Figure 4. Bone allograft powder condensed. 


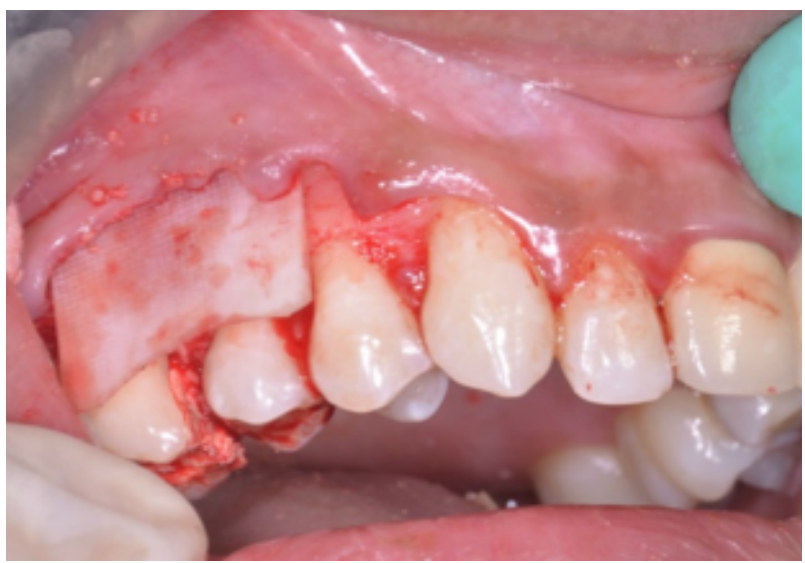

Figure 5. Membrane placed over the graft.

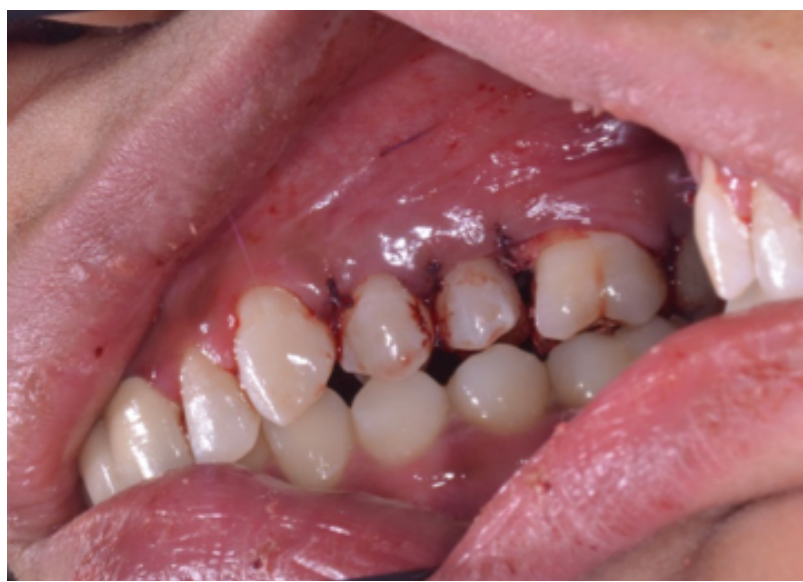

Figure 6. Interrupted silk suture placed.

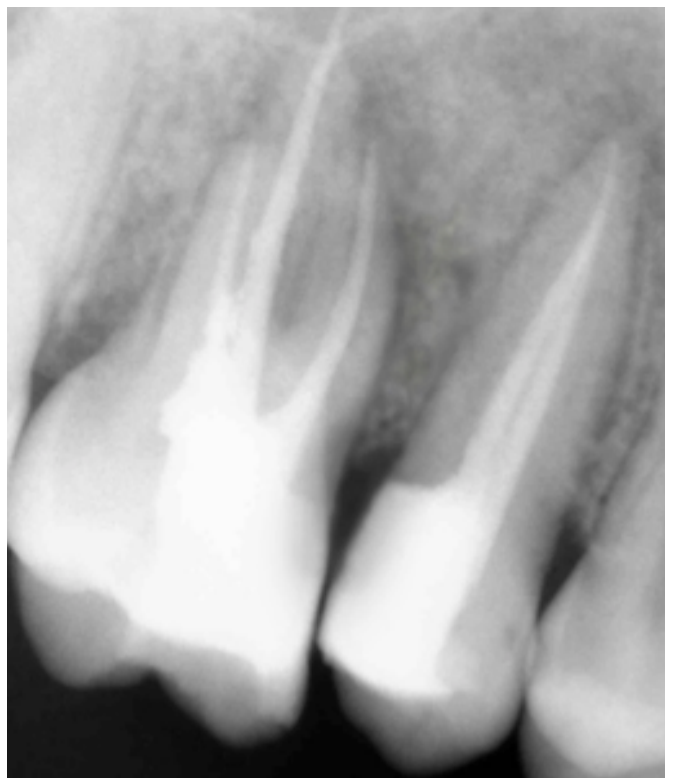

Figure 7. Hard tissue healing after 3 months.

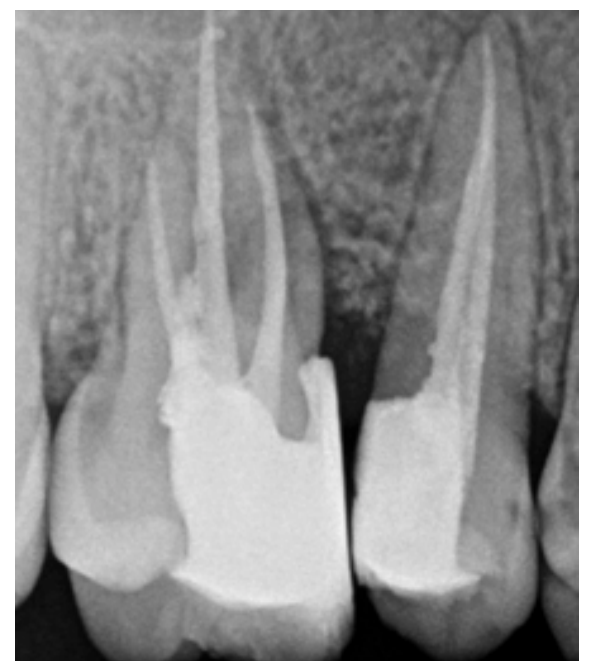

Figure 8. 2-year follow up.
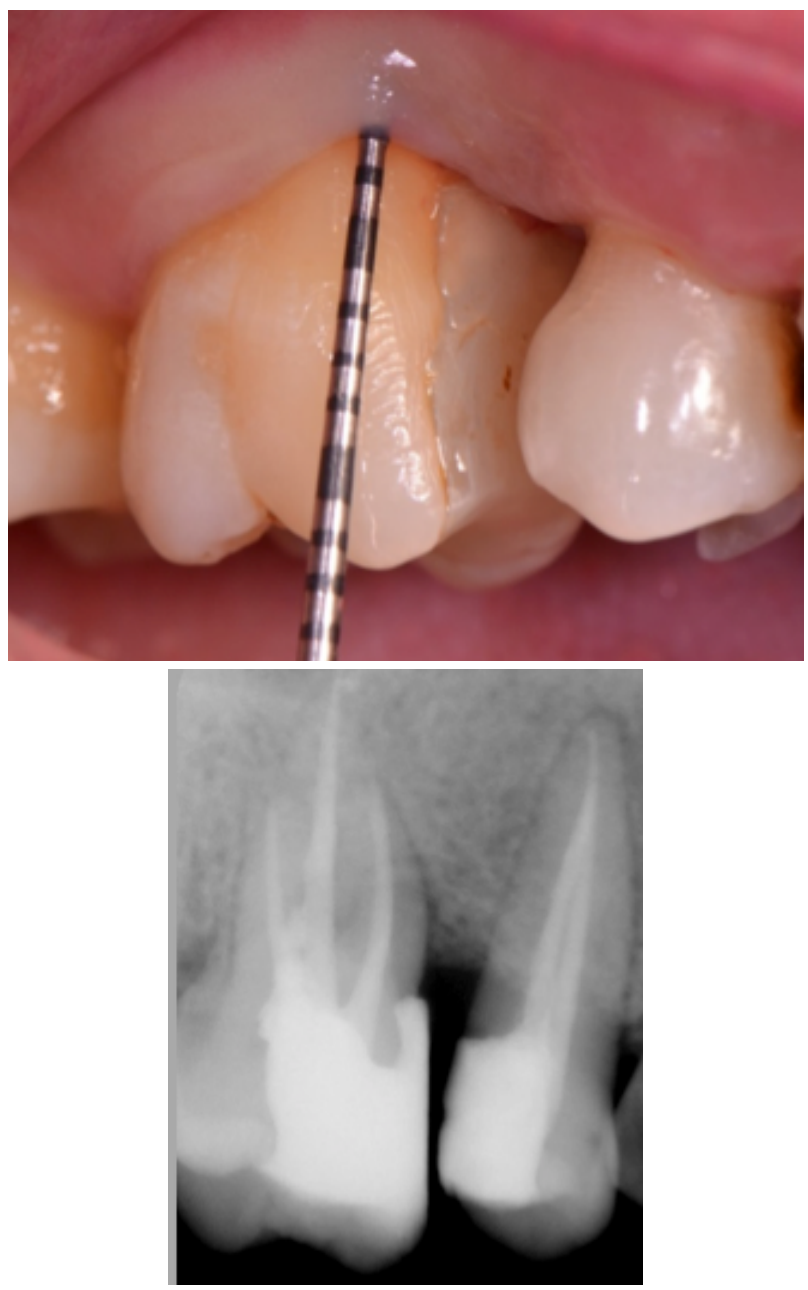

Figure 9. 5-year follow-up. 


\section{DISCUSSION}

Endo-perio relationship is well-documented and comprehensively explained in numerous clinical studies. A study mentioned that combined endo-perio lesions are endodontically induced periapical lesion on a tooth that is periodontally involved as well (3) and endo-perio lesions are responsible for loss of $50 \%$ of the involved teeth (4). In another clinical study, it has been revealed that how pulp inflammation from involved lateral canals spreads and causes pulp damage leading to its necrosis and periapical lesions (5). In such cases substantial damage to periodontal apparatus occurs which requires root canal treatment of the affected tooth/teeth (3). The diagnosis of such teeth is difficult and depends on pulp sensibility testing. If bone defects are radiographically and clinically visible but the pulp response to a pulp test is normal, then the inflammation is periodontal in origin. If the pulp shows negative response to the thermal tests, then inflammation source may be endodontic in origin which has caused the periodontal lesion via apical foramen or accessory canals (6). A number of studies have suggested that combined periodontic endodontic therapy is mandatory for effective healing of such a combined lesion (7)

In this case, after careful clinical and radiographic examination, the two adjacent teeth \# 15 and 16 were found insensible to thermal tests which led to establish diagnosis of pulp necrosis in the affected teeth. The RCT of the affected teeth was imperative to perform before periodontal correction. Following RCT, the patient's teeth were meticulously scaled and root-planed to further lower the bacterial load from the periodontal lesion site as RCT followed by NSPT exhibits improvement of clinical parameters long with alveolar bone creation (8).

Guided tissue regeneration provides a viable option for regeneration of damaged/ diseased periodontal tissues. GTR is an alternative preference for teeth having questionable to poor prognosis (9). Current literature suggests that periodontal regeneration is extremely effective and gives longevity to underlying supporting structures and increases tooth survival rate. According to the findings of a study, the periodontally regenerated teeth appear to be more cost effective than replacing them with implants (10). Though implant placement is also promptly recommended by implantologists in periodontally compromised clinical situations but a study comparing the success rate of implants versus RCT mentioned that success rate in implant placement is $74 \%$ whereas in root treated teeth it is $84 \%$ after 7-9 years of treatment (11). RCT followed by regenerative periodontal therapy appears to be better choice than going for extraction followed by implant in cases with endodontic-periodontal involvement with dubious prognosis.

\section{CONCLUSION}

Successful management and subsequent repair of bone defect in this case, suggests that endo-perio involved teeth having questionable to poor prognosis can be effectively treated.

\section{REFERENCES}

1. Sanz M., van Winkelhoff A.J., Periodontology WGotSEWo. Periodontal infections: understanding the complexityconsensus of the Seventh European Workshop on Periodontology. Journal of Clinical Periodontology. 2011; 38: 3-6.

2. Liu J., Kerns D.G. Mechanisms of guided bone regeneration: a review. The open dentistry journal. 2014; 8: 56-65. PubMed PMID: 24894890. Pubmed Central PMCID: PMC4040931. Epub 2014/06/05. eng.

3. Simon P., Jacobs D. The so-called combined periodontal-pulpal problem. Dental Clinics of North America. 1969; 13 (1): 45-52. 
4. Bender I. Factors influencing the radiographic appearance of bony lesions. Journal of endodontics. 1982; 8 (4): 161-70.

5. Langeland K., Rodrigues H., Dowden W. Periodontal disease, bacteria, and pulpal histopathology. Oral Surgery, Oral Medicine, Oral Pathology. 1974; 37 (2): 257-70.

6. Meng H.X. Periodontic-endodontic lesions. Annals of Periodontology. 1999;4(1):84-9.

7. Dongari A., Lambrianidis T. Periodontally derived pulpal lesions. Dental Traumatology. 1988; 4 (2): 49-54.

8. Vakalis S.V., Whitworth J.M., Ellwood R.P., Preshaw P.M. A pilot study of treatment of periodontal-endodontic lesions. International dental journal. 2005; 55 (5): 313-8.
9. Cortellini P., Stalpers G., Mollo A., Tonetti M.S. Periodontal regeneration versus extraction and prosthetic replacement of teeth severely compromised by attachment loss to the apex: 5-year results of an ongoing randomized clinical trial. Journal of clinical periodontology. 2011; 38 (10): 915-24.

10. Schwendicke F, Graetz C, Stolpe M, Dörfer CE. Retaining or replacing molars with furcation involvement: A cost-effectiveness comparison of different strategies. Journal of clinical periodontology. 2014; 41 (11): 1090-7.

11. Setzer F., Kim S. Comparison of long-term survival of implants and endodontically treated teeth. Journal of dental research. 2014; 93 (1): 19-26. 